\title{
Genetic variation in the feeding efficiency of maize genotypes evaluated from experiments with fattening bulls
}

\author{
Y Barrière *, JC Émile, Y Hébert \\ INRA, Station d'amélioration des plantes fourragères, F-86600 Lusignan, France
}

(Received 18 July 1995; accepted 27 October 1995)

\begin{abstract}
Summary - Genetic variation in the feeding efficiency of maize genotypes was evaluated from experiments with fattening bulls. Maize genotypes were chosen to represent a range of digestibilities from previous experiments with standard sheep. The variation in daily gains observed when bulls were fattened with hybrids of low digestibilities or high energy values was about $65 \mathrm{~g}$ per animal. When fed to bulls, the voluntary silage maize intake could be different in hybrids with similar energy values. Thus, differences in feeding efficiency of maize hybrids were related both to digestibility and ingestibility, especially for late hybrids among which variations for digestibility appeared lower than among earlier ones. As observed with brown-midrib (bm3) hybrids, genotypes with a greater digestibility and/or ingestibility might allow a reduced supply of energy-giving concentrates in the diet. Bull performances appeared to be related to both sheep digestibility estimates and the enzymatic solubility values of the whole plants, but this link could have been overestimated due to the similarity among hybrids in grain and dry-matter content of the silages. For maize breeders, the prediction of hybrid efficiency in cattle rearing must include both digestibility and ingestibility factors. Because the stover digestibility and the starch content can be predicted reliably with the use of NIRS (near infrared reflectance spectroscopy) calibration, the most important challenge for maize breeders in the future will probably be the development of a criterion for the intake prediction.
\end{abstract}

\section{Zea mays = maize / silage / digestibility / ingestibility / bull fattening}

Résumé - Variabilité génétique de la valeur alimentaire de génotypes de maïs ensilés évaluée à partir d'essais sur taurillons à l'engrais. Des essais sur taurillons ont été mis en place pour étudier l'effet de la variabilité génétique de la valeur alimentaire de différents génotypes de maïs, préalablement triés sur leur digestibilité et leur valeur énergétique mesurées avec des moutons standard. Quand les taurillons sont alimentés avec des hybrides de bonne valeur énergétique, comparativement à des hybrides de faible valeur énergétique, les gains moyens quotidiens sont, en moyenne, de $65 \mathrm{~g}$ supérieurs. Des hybrides ayant des valeurs énergétiques proches peuvent être ingérés de façon différente, sans que cela soit prévisible d'après les valeurs d'ingestibilité mesurées sur moutons. L'efficacité alimentaire d'un hybride de maïs destiné à l'alimentation de taurillons, sous forme d'ensilage, apparaît liée à son ingestibilité autant qu'à sa digestibilité, en particulier pour les hybrides tardifs dont la variabilité pour la digestibilité paraît plus faible. Ainsi que cela a déjà été observé avec du matériel brown-midrib-3 (Malterre et al, 1985), lutilisation de tels hybrides plus ingestibles ou plus digestibles permet une complémentation énergétique réduite, sans diminution des performances zootechniques. Une bonne liaison existe entre les croissances des animaux et les valeurs de solubilité enzymatique des hybrides, même si elle est peut-être exacerbée ici en raison des teneurs en grain et matière sèche semblables des

\footnotetext{
* Correspondence and reprints
} 
hybrides comparés. La sélection d'hybrides de maïs à vocation ensilage doit donc prendre en compte ce critère de valeur énergétique, ce qui semble tout à fait réalisable avec l'utilisation d'une solubilité enzymatique, prédite en NIRS, sur des échantillons de plantes entières, et recalculée pour la partie «non amidon, non glucides solubles". L'objectif de travail le plus important est sans doute maintenant d'approcher la compréhension des phénomènes de variabilité de l'ingestibilité, et de définir des critères de prédiction utilisables en sélection.

Zea mays = maïs $/$ ensilage $/$ digestibilité $/$ ingestibilité $/$ taurillons

\section{INTRODUCTION}

Maize is presently a major forage crop for cattle, and more than 3300000 ha are harvested every year in the European Union for making silage. Silage maize is used as an energy source and its low protein content is easily corrected with soya or sunflower cakes. Breeders and farmers have long relied on the assumption that a good grain maize was also the most suitable for silage. But genetic variation in digestibility and energy value has been clearly demonstrated among experimental and registered hybrids from in vitro or in vivo experiments. As reported by Deinum et al (1984), Dijkstra and Becker (1960) probably performed one of the first in vivo comparisons of silage maize with standard sheep in digestibility crates. Their results were later confirmed by Andrieu and Demarquilly (1974), Gallais et al (1976), Deinum et al (1984) and Barrière et al (1991). Variation in digestibility of organic matter (DOM) and crude fibre (DCF) was also investigated by Barrière et al (1992), on a much broader maize genetic basis. Observed values ranged between 65.0 and $73.5 \%$ for DOM and 39.0 and $62.2 \%$ for DCF, when investigating registered genotypes whatever their earliness. Hunt et al (1992) also pointed out differences in ruminal fermentability (in situ measurements) of whole plants and stover of maize affected by genotypes. However, genetic variation for maize digestibility has mostly been investigated for theoretical and breeding purposes through in vitro tests such as an enzymatic solubility test, or a Tilley and Terry (1963) rumen fluid test, often predicted through NIRS (near infrared reflectance spectroscopy) calibrations (Gallais et al, 1976; Deinum and Bakker, 1981; Vattikonda et Hunter, 1983; Deinum and Struik, 1985; Dhillon et al, 1990; Dardenne et al, 1993; Wolf et al, 1993; Roth, 1994).

The effects of a variation for feeding efficiency in maize were first investigated from a genetic point of view, with either dairy cattle or fattening bulls, when comparing normal and brown-midrib (bm3 and $b m 1$ ) hybrids (for a review, see Barrière and Argillier, 1993; Coors et al, 1994).
With normal maize hybrids, the variation in milk yield observed with dairy cows fed with a low and then a high energy-providing hybrid was about 1 to $2 \mathrm{~kg}$ per animal per day, and the difference in body weight gain was about 100 to $300 \mathrm{~g}$ per animal per day. Moreover, the voluntary intake could be very different according to the genotype fed to dairy cows, even if no difference in intake was observed in sheep measurements (Barrière et al, 1995).

Therefore, the objective here was to measure how the differences in DOM, DCF and energy values measured in sheep, and previously confirmed in experiments with dairy cattle, were expressed in meat yield when highly performing bulls were fattened with silage maize hybrids which may differ in feeding value.

\section{MATERIALS AND METHODS}

Maize hybrids were grown, irrigated, harvested and ensiled according to usual farming practices each year from 1987 to 1993 . There were 10 separate fattening experiments. In each experiment, the 2 hybrids compared were harvested at a time when their dry-matter (DM) content was the same, whatever their earliness. Fattening comparisons were performed either on early and medium-early hybrids, or on medium-late hybrids. The hybrids used were all registered (Rh161 was tested under a confidentiality clause), except for Lu2003, which was purposely bred in INRA-Lusignan for its low feeding value. Maize hybrids with low or high feeding quality traits were chosen as already seen in prior experiments with standard sheep, in order to make it possible either to study most of the range of available variation, or to compare maize with nearly equal values. In the sheep experiments, according to Andrieu and Demarquilly (1987), 3 feeding value traits had been investigated, DOM, DCF, voluntary intake $\left(\mathrm{g} / \mathrm{kgW}^{0.75}\right)$, and 3 had been computed, UFV, a unit of net feed energy for meat production developed by INRA, PDIN and PDIE ( $\mathrm{g} / \mathrm{kg}$ DM), 2 values of the silage content of truly digestible protein in the small intestine, also developed by INRA, and estimated according to the availability of nitrogen and energy respectively. Such measurements were also investigated on silages used in bull fattening, and the results gathered with the previous data (table I). In vitro digestibility of dry matter (IVDDM) of hybrids was evaluated with the usual enzymatic solubility (Lila et al, 
Table I. Feeding values traits, obtained from experiments with sheep, of the hybrids selected for fattening trials.

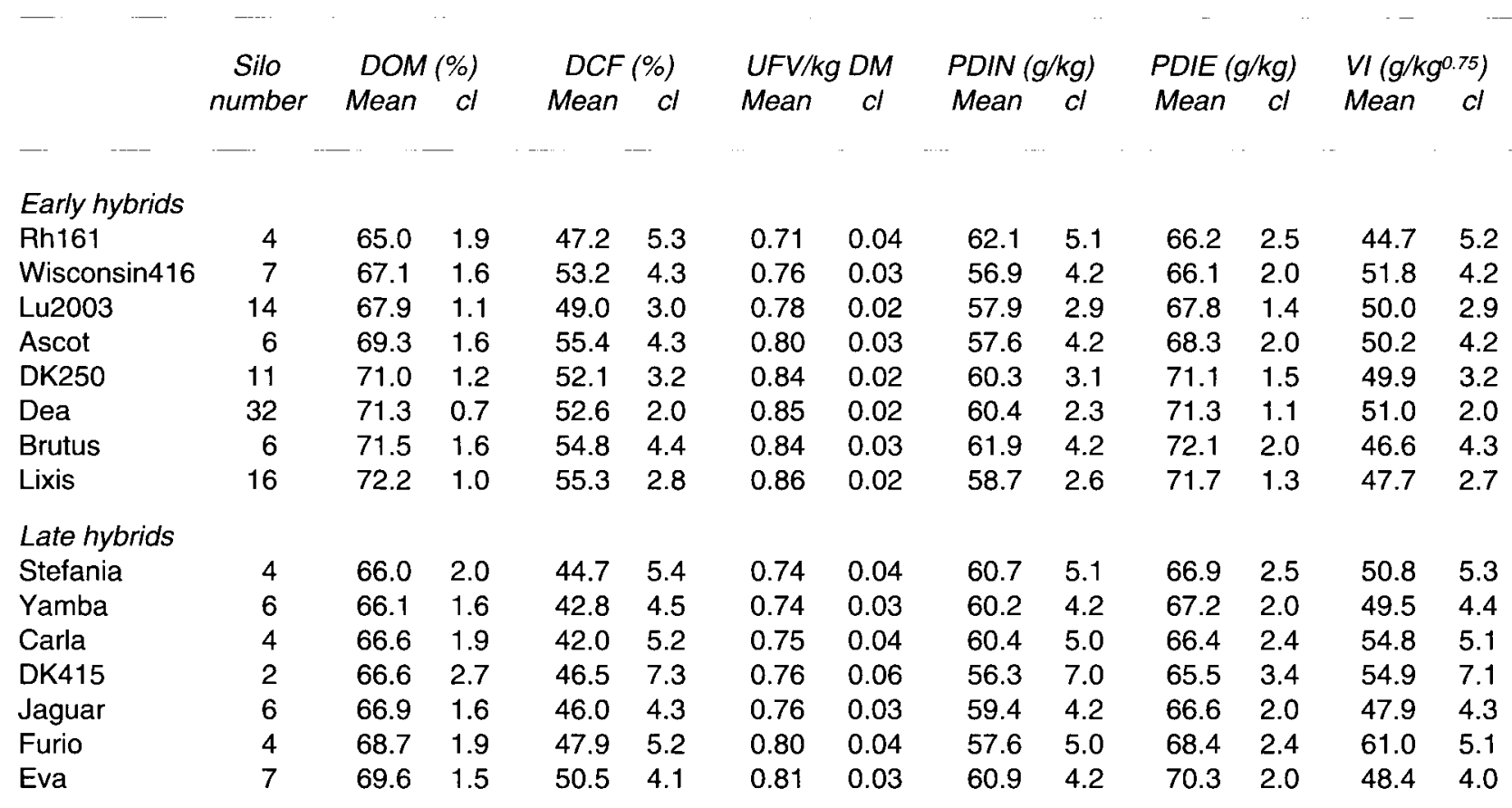

$\mathrm{DOM}=$ digestibility of organic matter, $\mathrm{DCF}=$ digestibility of crude fibre, UFV = meat feed unit, PDIN, PDIE = protein content according to the availability of nitrogen or energy, $\mathrm{VI}=$ voluntary intake, $\mathrm{cl}=$ confidence limit at the $5 \%$ level.

1986) taken from a number of samples collected from silage given to animals (table II).

Experiments with fattening bulls began in January following the harvest of maize, and lasted $171 \mathrm{~d}$ on

Table II. IVDDM values of hybrids used for bull fattening.

$\underset{\text { Mean }}{\operatorname{IVDDM}(\%)} \mathrm{cl}$

$\begin{array}{lll}\text { Early hybrids } & & \\ \text { Rh161 } & 74.3 & 2.7 \\ \text { Wisconsin416 } & 79.1 & 2.2 \\ \text { Lu2003 } & 75.6 & 1.5 \\ \text { Ascot } & 77.2 & 2.2 \\ \text { DK250 } & 81.4 & 1.6 \\ \text { Dea } & 81.5 & 1.0 \\ \text { Brutus } & 82.6 & 2.3 \\ \text { Lixis } & 81.8 & 1.4 \\ \text { Late hybrids } & & \\ \text { Stefania } & 79.4 & 2.8 \\ \text { Yamba } & 78.6 & 2.3 \\ \text { Carla } & 80.2 & 2.7 \\ \text { DK415 } & 80.6 & 3.8 \\ \text { Jaguar } & 79.9 & 2.2 \\ \text { Furio } & 80.7 & 2.7 \\ \text { Eva } & 77.5 & 2.1\end{array}$

average (table III). Charolais bulls were used for all these experiments. Pre-experimental measurements began 1 month after the purchase of young grazing bulls. After a 4 week pre-experimental period, the animals were randomly assigned experimental diets according to body weight and average daily gain. In order to compare 2 different hybrids, 2 sets of 10,12 or 24 animals depending on the experiment (table III) were made up so that the sets were on average similar, and similar within the variation range of these traits, allowing a fair comparison of the maize silages fed. Bulls, housed in a freestall barn, were fed maize silage daily in quantities which produced approximately $15 \%$ refusals. For each diet, half of the bulls were individually fed, using 'Calan-type' electromagnetic feeding doors, and half were fed from a trough. The amounts of voluntary intake and refusal were recorded daily, $4 \mathrm{~d}$ a week, individually for the bulls fed in doors, and in batch for the others. As usual, a commercial concentrate providing nitrogen, minerals and vitamins was added to the ad libitum maize silage according to requirements ('Bullvo 1500', $1.22 \mathrm{~kg} / \mathrm{animal} / \mathrm{d}$ ). Live body weights were recorded for each bull on 2 consecutive days at the beginning and at the end of the experimental period, as well as once every fortnight during the experiment. Because of its abnormal behaviour, 1 bull fed Lixis was discarded from experiment 5 .

Basic data were obtained for each animal and each maize diet as an average value for each week of experiment. The variance analysis of intake was computed for each experiment through a model which included week, animal, maize diet effects and animal $x$ 
Table III. General data for the bull fattening experiments.

\begin{tabular}{|c|c|c|c|c|c|c|c|}
\hline 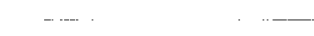 & & & $\cdots-\cdots$ & $-\cdots$ &.- & & $\ldots$ \\
\hline Experiments & $\begin{array}{c}\text { Year } \\
\text { of bull } \\
\text { fattening }\end{array}$ & $\begin{array}{l}\text { Heat-units during } \\
\text { maize cropping } \\
\left.\text { (basis } 6^{\circ}\right)\end{array}$ & $\begin{array}{l}\text { Length of } \\
\text { experiments } \\
\text { (d) }\end{array}$ & $\begin{array}{c}\text { Number } \\
\text { of } \\
\text { bulls/diet }\end{array}$ & $\begin{array}{c}\text { Energy value } \\
\text { of 'Bullvo' } \\
\text { (UFV/kgDM) }\end{array}$ & $\begin{array}{c}\text { PDIN value } \\
\text { of 'Bullvo' } \\
(g / \mathrm{kgDM})\end{array}$ & $\begin{array}{c}\text { PDIE value } \\
\text { of 'Bullvo' } \\
(g / k g D M)\end{array}$ \\
\hline - - - - - - & & $\cdots \cdots$ & & $\cdots-\cdots$ & $\cdots-$ & & -—. \\
\hline Early hybrids & & & & & & & \\
\hline 1) Dea/Wisconsin416 & 1988 & 1597 & 182 & 12 & 0.80 & 220 & 145 \\
\hline 2) Dea/DK250 & 1989 & 1503 & 182 & 12 & 0.80 & 220 & 145 \\
\hline 3) Lixis/Rh161 & 1991 & 1381 & 168 & 10 & 0.86 & 230 & 165 \\
\hline 4) Brutus/Ascot & 1991 & 1441 & 168 & 10 & 0.86 & 230 & 165 \\
\hline 5) Lixis/Lu2003 & 1992 & 1492 & 140 & 10 & 0.86 & 250 & 165 \\
\hline Late hybrids & & & & & & & \\
\hline 6) Jaguar/Eva & 1989 & 1598 & 182 & 12 & 0.80 & 220 & 145 \\
\hline 7) Jaguar/DK415 & 1990 & 1577 & 182 & 12 & 0.80 & 220 & 145 \\
\hline 8) Furio/Carla & 1990 & 1589 & 182 & 12 & 0.80 & 220 & 145 \\
\hline 9) Furio/Carla & 1993 & 1645 & 182 & 12 & 0.86 & 250 & 165 \\
\hline 10) Yamba/Stefania & 1994 & 1762 & 161 & 24 & 0.92 & 255 & 165 \\
\hline
\end{tabular}

PDIN, PDIE: protein content according to the availability of nitrogen or energy.

maize diet interaction. Each of the individually fed animals was usually given a statistical weight equal to 1 . The average value observed in animals fed from a trough was considered as an extra statistic for an additional bull, the statistical weight of which was computed assuming that each of these animals had a statistical weight of 0.5 , half as much as those individually fed. The results observed between each week of the experiments were not independent, and could be assimilated to statistically repeated measures. So, according to Little and Hills (1978), and because the objective was to test between group (maize diet) effects, a univariate test was investigated and the $F$ test was therefore computed as in a split-plot design, as the ratio of between (maize diet) and within (interaction) effects. This manner of computing led to $F$ ratios similar to those obtained on the average values of the weeks. For the estimate of the effect of diet on gains in body weight, an adequate multivariate test has been developed by Box (1950) in an analysis of growth curves. The variates to be considered are the weight gains between each weighing period. An $F$ approximation was obtained from the ratio between the sums of squares and products for error and the sums of squares and products for error plus the sums of squares and products for treatment, testing the hypothesis that the mean value for each of the variates is the same from treatment to treatment. More general approaches to the analysis of repeated measurements were latter suggested by Diggle (1988) and Huggins (1993) using likelihood-based methods. As far as we know, software using such a precise statistical approach of repeated measures is not yet available on the market.

\section{RESULTS AND DISCUSSIONS}

The results of each of the 10 experiments are listed in tables IV and $V$ for early and medium early hybrids and in tables VI and VII for medium

Table IV. Results of bull fattening with early hybrids (mean values).

\begin{tabular}{|c|c|c|c|c|c|c|c|c|c|c|}
\hline & \multicolumn{2}{|c|}{ Experiment 1} & \multicolumn{2}{|c|}{ Experiment 2} & \multicolumn{2}{|c|}{ Experiment 3} & \multicolumn{2}{|c|}{ Experiment 4} & \multicolumn{2}{|c|}{ Experiment 5} \\
\hline & Dea & Wis.416 & Dea & $D K 250$ & Lixis & $R h 161$ & Brutus & Ascot & Lixis & Lu2003 \\
\hline Maize grain (\%) & 52.9 & 44.8 & 51.0 & 51.9 & 42.9 & 42.7 & 46.4 & 44.1 & 46.9 & 45.8 \\
\hline Maize DM (\%) & 35.8 & 35.7 & 35.7 & 38.0 & 35.9 & 36.3 & 36.5 & 41.1 & 39.8 & 41.5 \\
\hline Maize intake (kg) & 9.8 & 10.0 & 9.3 & 9.6 & 8.4 & 8.8 & 8.5 & 9.4 & 8.6 & 8.5 \\
\hline Concentrates $(\mathrm{kg})$ & 1.2 & 1.2 & 1.2 & 1.2 & 1.2 & 1.2 & 1.2 & 1.2 & 1.2 & 1.2 \\
\hline Initial weight (kg) & 413 & 414 & 399 & 396 & 440 & 444 & 443 & 442 & 442 & 440 \\
\hline Final weight $(\mathrm{kg})$ & 679 & 669 & 664 & 661 & 676 & 670 & 677 & 672 & 649 & 639 \\
\hline Daily gain $(\mathrm{g})$ & 1469 & 1405 & 1458 & 1456 & 1410 & 1346 & 1393 & 1368 & 1518 & 1415 \\
\hline
\end{tabular}


Table V. Results of bull fattening with early hybrids ( $F$ values).

\section{F test intake Box $\mathrm{F}$ test daily gain}

$\begin{array}{lll}\text { Dea/Wisconsin416 } & 2.82 \mathrm{~ns} & 1.80^{\star} \\ \text { Dea/DK250 } & 1.59 \mathrm{~ns} & 1.70 \mathrm{~ns} \\ \text { Lixis/Rh161 } & 0.58 \mathrm{~ns} & 4.42^{\star *} \\ \text { Brutus/Ascot } & 3.71^{\star} & 4.77^{\star \star} \\ \text { Lixis/Lu2003 } & 0.12 \mathrm{~ns} & 3.34^{\text {* }}\end{array}$

${ }^{\star} P<0.10 ;{ }^{\star \star} P<0.01$.

late hybrids. In all experiments, DM contents of maize silages were suitable for bull fattening. As expected, within each comparison, the DM contents of maize hybrids were similar, except for a high value for Ascot in the experiment 4, due to a late harvest during a dry summer, and a slightly higher value for Yamba, compared to Stefania in experiment 10. Furio and Carla were compared twice in 2 separate experiments; the DM content in the first was 5 points higher. In each of the 10 experiments, the grain content of each pair of hybrids compared was almost equal, except for a lower value of Wisconsin416 during the first trial, which is a genetic characteristic of this hybrid registered many years ago. In any case, nitrogen content in the diet agreed with the nutritional recommendations (Geay and Micol, 1988), and could never be a limiting factor, whatever hybrid was being observed.

\section{Early hybrids}

Voluntary intakes of maize were similar in each pair of hybrids, except for a higher intake for

Table VII. Results of bull fattening with late hybrids, ( $F$ values).

\section{$\mathrm{F}$ test intake}

$2.47 \mathrm{~ns}$

4.19 *

0.79 ns

$0.92 \mathrm{~ns}$

$0.02 \mathrm{~ns}$
Box F test

daily gain

$\begin{array}{llc}\text { Jaguar/Eva } & 2.47 \mathrm{~ns} & 4.52^{\star \star \star} \\ \text { Jaguar/DK415 } & 4.19^{\star} & 5.60^{\star \star \star} \\ \text { Furio/Carla a } & 0.79 \mathrm{~ns} & 1.10 \mathrm{~ns} \\ \text { Furio/Carla b } & 0.92 \mathrm{~ns} & 0.85 \mathrm{~ns} \\ \text { Yamba/Stefania } & 0.02 \mathrm{~ns} & 1.688^{\star \star} \\ & & - \\ & & \end{array}$

Ascot, due to its higher DM content. A lower intake of Lixis was previously observed by Istasse et al (1990) in bull fattening experiments and by Barrière et al (1995) in dairy cow experiments, but this tendency did not prove to be very definite here. In spite of this, this hybrid always led to higher or equal animal performances than those showing a greater voluntary intake.

Daily gains in bulls were similar with Dea and DK250, 2 hybrids with a similar energy value according to sheep measurements and a similar grain content. Because experiments 3 and 4 were joint experiments, it was also possible to conclude the same for Lixis and Brutus, and for Rh161 and Ascot. As expected, hybrids of different energy values according to sheep measurements led to different performances in bulls. According to the Box $F$ test, the differences in average daily gains were significant when comparing Dea and Wisconsin416, Lixis and Rh161, Brutus and Ascot, and Lixis and Lu2003. Ascot was less efficient than Brutus, despite its higher DM content, and despite a higher intake of maize silage. The differences in daily gains observed

Table VI. Results of bull fattening with late hybrids (mean values).

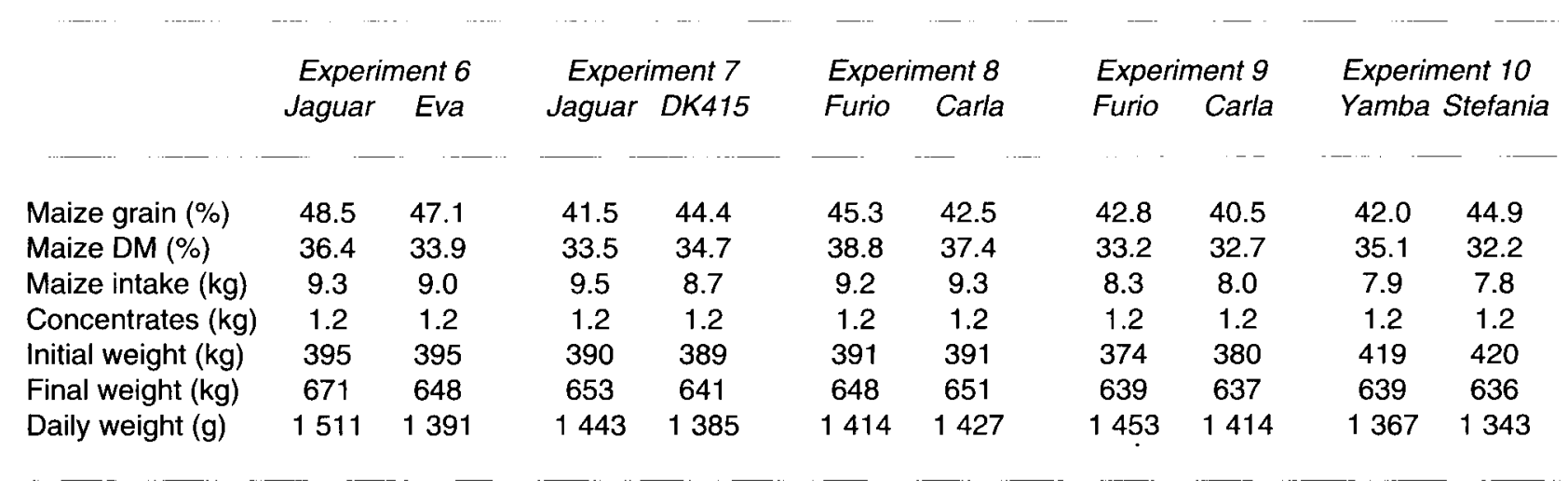


with fattening bulls fed a low or high digestible hybrid as seen in the previous sheep measurements were about 25-105 g per animal. These results concurred with those of Istasse et al (1990) who observed daily gains of $200 \mathrm{~g}$ lower with animals fed Ascot than those fed Lixis, 2 other intermediate hybrids. Similar results have also been obtained by Carpentier et al (1994) and Haurez et al (1994); daily gains were 80 and $160 \mathrm{~g}$ higher, respectively, with the best hybrid of each pair being compared. In our experiments the differences in daily gains between hybrids were lower. No satisfactory explanations could be given. However, in Istasse et al's experiments, bulls were fed limited amounts, nearing ad libitum, so that the maize silage was $2 / 3$ of the total DM diet $(8.5 \mathrm{~kg} /$ animal $/ \mathrm{d})$. In Carpentier et al's and Haurez et al's experiments, bulls were fed ad libitum, but maize intakes neared only $7 \mathrm{~kg} / \mathrm{animal} / \mathrm{d}$ within a diet close to $9.1 \mathrm{~kg} / \mathrm{ani}-$ $\mathrm{mal} / \mathrm{d}$. In a growth trial with beef steers (Hunt et al, 1993), daily gains were $70 \mathrm{~g}$ higher with the best of the 2 hybrids, when animals were fed only $5.1 \mathrm{~kg}$ DM maize/d (2/3 of the total diet). Differences in daily gains between hybrids and their isogenic $b m 3$ counterparts were higher than those between normal hybrids, with an average difference reaching $240 \mathrm{~g}$ (Malterre et al, 1985).

\section{Late hybrids}

A significantly higher voluntary intake of maize silage was observed in animals fed Jaguar silage, nearing $1 \mathrm{~kg}$ more than those fed DK415. Intake of Jaguar also tended to be slightly greater than intake of Eva. Compared with Stefania, intake of Yamba was lower than expected considering its higher DM content. Daily gains were higher for Jaguar when it was compared to either Eva or DK415, and this was probably due to its higher ingestibility and probably also to its higher digestibility. Daily gains with Furio and Carla were similar, even if daily gains of Furio tended to be slightly higher than those of Carla when the DM content of silages was lower than $35 \%$. Yamba was very slightly more efficient than Stefania, but this could also be due to its higher DM content.

\section{Relationships between maize efficiency in bulls, and DOM or IVDDM values}

Two groups of early hybrids emerged from the IVDDM measurements, separating the best from the weaker, thus confirming the sheep evaluations even though the precise ranking was not similar. Late hybrids happened to be less variable in feeding quality traits than the earlier ones whether these observations came from sheep or IVDDM measurements. When taken from IVDDM measurements, late hybrids appeared to be of intermediate value between the highest and lowest early hybrids, whereas sheep estimates ranked them nearer the poorest early hybrids. Nevertheless, hybrids whose predicted energy or digestibility values from sheep or IVDDM measurements were lower, led to lower fattening performances, despite the differences in body gains in bulls which were sometimes lower than expected. As expected, hybrids with similar predicted energy values led to similar performances in bulls. The average difference between hybrids with a poor or a good digestibility was $65 \mathrm{~g}$ more in daily body weight gain, equivalent to 0.02 UFV per $\mathrm{kg}$ silage maize DM. Some hybrids might be of a much higher ingestibility than others in bulls, but voluntary intake by sheep did not appear to be similar to the intake of bulls. It is also worth noticing that IVDDM measurements were unable to predict the differences of intake when the different maize hybrids were fed to bulls. These variations of silage intake could only be shown through bovine cattle investigations, concurring with bibliographical data (Demarquilly and Weiss, 1971; Chesnot and Martin-Rosset, 1985; Moran et al, 1988; Dulphy et al, 1994). However Rh161, DK415 and Eva displayed unquestionably lower feeding values than Lixis and Jaguar, considering the maize intake and the animal performances. Regarding the IVDDM and fattening results, the feeding value of Eva probably appeared overestimated in the studies on sheep. Therefore, the high efficiency of a maize hybrid in bull fattening related to both its digestibility and its ingestibility, especially in late hybrids among which variations in digestibility were low. As observed with $b m 3$ hybrids (Malterre et al, 1985), genotypes with a greater digestibility and/or ingestibility might allow a reduced supply of energy-giving concentrates in the diet.

\section{CONCLUSIONS}

For maize breeders, the prediction of the efficiency of the hybrid for cattle rearing must include digestibility and ingestibility factors. When testing a number of genotypes, digestibility should be reliably predicted, with or without a NIRS calibration, by the use of an enzymatic solubility. The 
use of enzymatic solubility of the whole plant is not optimal because such a method cannot distinguish hybrids with a high grain content and a low stover digestibility from hybrids with a lower grain content, but with a higher stover digestibility. A pertinent enzymatic solubility for breeding maize for its feeding value must be free of the obscuring effect of starch content, and as similar as possible to the cell-wall digestibility. One of the easiest ways would be to investigate the in vitro solubility of the 'non-starch and non-soluble carbohydrate' part of the plant, computed after NIRS prediction of the IVDDM, starch and soluble carbohydrate contents on whole plant samples (Argillier et al, 1995). The most important challenge for the maize breeder will probably now be the adjustment of a criterion for the maize hybrid intake prediction, taking into account the biochemical and physical characteristics of the forage, as reported by Minson and Wilson (1994).

As reported by Raymond et al (1986), the profit margin increases by $300 \mathrm{Ecu} / \mathrm{ha}$ when the daily gain increases by $50 \mathrm{~g}$. Based on ingredient costs, the first hybrid compared by Hunt et al (1993) would be worth 650 Ecus more per ha than the second. As pointed out by Utz et al (1994), the greatest economic maize breeding traits, at high animal performance levels, are those related to the energy content of the plant, rather than those related to plant yield. But, at low animal performance levels, forage yield appeared as an important economic trait. These findings are not independent of both the maize ingestibility and the intake capacity of the animals. Therefore, in the case of high performing animals such as fattening bulls, each farmer in the EU should attain economic benefits by the use of highly digestible and ingestible maize hybrids, even if the forage yield of the hybrid does not reach the highest known value for its earliness group.

\section{ACKNOWLEDGMENTS}

The authors are grateful to all contributors of these experiments for their technical assistance, especially $R$ Chargelègue, $C$ Huguet and $B$ Boutin. We thank $M$ Rives for his helpful advice and criticism, and $A$ de Pourtalès for the linguistic revision of the manuscript.

\section{REFERENCES}

Andrieu J, Demarquilly C (1974) Valeur alimentaire du maïs fourrage. II. Influence du stade de végétation, de la variété, du peuplement, de l'enrichissement en épis et de l'addition d'urée sur la digestibilité et l'ingestibilité de l'ensilage de maïs. Ann Zootech 23, 1-25

Andrieu J, Demarquilly C (1987) Valeur nutritive des fourrages, tables et prévisions. Bull Tech CRZV Theix, INRA 70, 61-73

Argillier O, Barrière $Y$, Hébert $Y$ (1995) Genetic variation and selection criterion for digestibility traits of forage maize. Euphytica 82, 175-184

Barrière $Y$, Demarquilly $C$, Hébert $Y$ et al (1991) Influences de la variabilité génétique et environnementale sur la digestibilité in vitro ou in vivo du maîs fourrage. agronomie 3, 151-157

Barrière Y, Traineau R, Émile JC (1992) Variation and covariation of silage maize digestibility estimated from digestion trials with sheep. Euphytica 59, 6172

Barrière $Y$, Argillier $O$ (1993) Brown-midrib genes of maize: a review. agronomie $13,865-876$

Barrière Y, Émile JC, Traineau R, Hébert Y (1995) Genetic variation in the feeding efficiency of maize genotypes evaluated from experiments with dairy cows. Plant Breed 114, 144-148

Box GEP (1950) Problems in the analysis of growth and wear curves. Biometrics 6, 362-389

Carpentier B, Haurez P, Joulie A, Rivoisy G (1994) Comparaison de la valorisation par des taurillons de 2 variétés de maïs choisies pour leur digestibilité différente (1992-1993, $2^{\mathrm{e}}$ essai). Report of AGPM, SEPROMA, Chambre d'agriculture 85 , Institut de l'élevage, October 1994, $43 p$

Chenost M, Martin-Rosset W (1985) Comparaison entre espèces (mouton, cheval, bovin) de la digestibilité et des quantités ingérées des fourrages verts. Ann Zootech 34, 291-312

Coors JG, Carter PR, Hunter RB (1994) Silage Corn. In: Specialty Corns (AR Hallauer, ed), CRC Press, London, 305-340

Dardenne $P$, Andrieu J, Barrière $Y$ et al (1993) Composition and nutritive value of whole maize plants fed fresh to sheep. 2. Prediction of the in vivo organic matter digestibility. Ann Zootech 42, 251 270

Deinum B, Bakker JJ (1981) Genetic differences in digestibility of forage maize hybrids. Neth $J$ Agric Sci 29, 93-98

Deinum B, Steg A, Hof G (1984) Measurement and prediction of digestibility of forage maize in the Netherlands. Anim Feed Sci Techn 10, 301-313

Deinum B, Struik PC (1985) Improving the nutritive value of forage maize. Proceedings of the 13th Congress Maize and Sorghum Section of Eucarpia. Wageningen, The Netherlands, 9-12 September $1985,77-90$

Demarquilly C, Weiss $P$ (1971) Liaisons entre les quantités de matière sèche de fourrage vert ingérées par les moutons et celles ingérées par les ovins. Ann Zootech 20, 119-134 
Diggle PJ (1988) An approach to the analysis of repeated measurements. Biometrics 44, 959-971

Dijkstra ND, Becker WR (1960) De verteerbaarheid en voederwaarde van verse en geenslieerde snijmais. Verslagen van landbouwkundige onderzoekingen Pudoc, Wageningen, 66, 14, $48 \mathrm{p}$

Dhillon BS, Paul C, Zimmer E, Gurrath PA, Klein D, Polmer WG (1990) Variation and covariation in stover digestibility traits in diallel crosses of maize. Crop Sci 30, 931-936

Dulphy JP, Jouany JP, Martin-Rosset W, Thériez M (1994) Aptitudes comparées de différentes espèces d'herbivores domestiques à ingérer et digérer des fourrages distribués à l'auge. Ann Zootech 43, 11-32

Gallais A, Pollacsek M, Huguet L (1976) Possibilités de sélection du maïs en tant que plante fourragère. Ann Amélior Plantes 26, 591-605

Geay Y, Micol D (1988) Alimentation des bovins en croissance et à l'engrais. In: Alimentation des bovins, ovins et caprins (R Jarrige, ed), INRA Éditions, 213-247

Haurez P, Joulie A, Mesnil C, Rivoisy G (1994) Comparaison de la valorisation par des taurillons de 2 variétés de maïs choisies pour leur digestibilité différente. Report of AGPM, SEPROMA, Chambre d'agriculture 85, Institut de l'élevage, January 1994 , $22 \mathrm{p}$

Huggins RM (1993) A robust approach to the analysis of repeated measures. Biometrics 49, 715-720

Hunt CW, Kezar W, Vinande R (1992) Yield, chemical composition, and ruminal fermentability of corn whole plant, ear, and stover as affected by hybrids. J Prod Agric 5, 286-290

Hunt CW, Kezar W, Hinman DD, Combs JJ, Loesche JA, Moen T (1993) Effects of hybrid and ensiling with or without a microbial inoculant on the nutritional characteristics of whole-plant corn. J Anim Sci $71,38-43$

Istasse L, Gielen M, Dufrasne L, Clinquart A, Van Eenaeme C, Bienfait JM (1990) Ensilage de maïs plante entière, comparaison de 4 variétés. 2 .
Performances zootechniques. Landbouwtijdschrift Revue de l'Agriculture 43, 996-1005

Lila M, Barrière $Y$, Traineau $R$ (1986) Mise au point et étude d'un test enzymatique de la digestibilité de fourrages pauvres ou riches en amidon. agronomie 6, 285-291

Little TM, Hills FJ (1978) Subplot as repeated observations. In: Agricultural Experimentation, Design and Analysis. John Wiley \& Sons, New York, 125-137

Malterre C, Bertin G, Gallais A, Huguet L, Micol D (1985) Le maïs brown-midrib plante entière. II. Utilisation sous forme d'ensilage par les taurillons. Bull Tech CRZV Theix, INRA 60, 43-58

Minson DJ, Wilson JR (1994) Prediction of intake as an element of forage quality. In: Forage Quality, Evaluation and Utilisation (GC Fahey, ed), American Society of Agronomy Inc, Crop Science Society of America Inc, Soil Science Society of America Inc, Madison, WI, 533-563

Moran JB, Lemerle R, Trigg TE (1988) The intake and digestion of maize silage-based by dairy cows and sheep. Anim Feed Sci Technol 20, 239-312

Raymond F, Citron G, Sagot L (1986) Effet de la qualité de l'ensilage de maïs sur les performances des taurillons. Perspectives Agricoles, suppl 105, 34-43

Roth GW (1994) Hybrid quality and yield differences for corn silage in Pennsylvania. J Prod Agric 7, 50-54

Tilley JMA, Terry RA (1963) A two-stage technique for the in vitro digestion of forage crops. $J \mathrm{Br}$ Grass/ Soc 18, 104-111

Utz HF, Melchinger AE, Seitz G, Mistele M, Zeddies J (1994) Economic aspects of breeding for yield and quality traits in forage maize. Plant Breeding 112 , 110-119

Vattikonda MR, Hunter RB (1983) Comparison of grain yield and whole plant silage production of recommended corn hybrids. Can J Plant Sci 63, 601-609

Wolf DP, Coors JG, Albrecht KA, Undersander DJ, Carter PR (1993) Forage quality of maize genotypes selected for extreme fiber concentrations. Crop Sci 33, 1353-1359 